\title{
Chemical studies on protein profile in albino rats under the effect of aqueous extracts of hibiscus rosa sinensis leaves and pomegranate (punica granatum) peels
}

\author{
Mahmoud, Sh.S. El-Sayed \\ Agricultural Biochemistry Department, Faculty of Agriculture, Ain Shams University, P. O. Box: 68, Hadayek \\ Shoubra 11241, Cairo, Egypt.
}

\begin{abstract}
Hibiscus rosa sinensis (HRS) leaves and pomegranate (punica granatum) peels (PP) have many medicinal applications. Effect of natural products (aqueous extract of Hibiscus rosa sinensis leaves (AEHRS leaves),pomegranate (punica granatum) peels (AEPP) and their mixture) on protein profile (total protein (TP), albumin (Alb) and albumin/globulin (A/G) ratio) concentrations at 7, 14 and 21 days of male albino rats was studied. Seventy two male albino rats were divided into twelve groups of six animals each $(n=6)$. The first group served as the normal health control (I). Animals of the second group (II) were induced hyperglycemia (diabetic control group) by injection of $65 \mathrm{mg} / \mathrm{kg}$ bw of streptozotocin (STZ). Three groups (III, IV and V) were given hibiscus aqueous leaves extracts (AEHRS) orally daily, at doses of 250,500 and $750 \mathrm{mg} / \mathrm{kg}$ bw respectively. Also, three groups (VI, VII and VIII) were given $P$. granatum aqueous peels extracts (AEPP) orally daily, at doses of 100, 200 and $300 \mathrm{mg} / \mathrm{kg}$ bw respectively. Finally, three groups those IX, X and XI were given mixture of AEHRS leaves and AEPP orally daily, at doses of (125/125,225/225 and 350/350 mg/kg bw). In addition, one of streptozotocin (STZ) rats group was treated with AEHRS leaves and AEPP mixture 400/400 mg/kg bw (XII) respectively. Serum was separated for estimation of total protein (TP) and albumin (alb) as well as albumin/globulin $(\mathrm{A} / \mathrm{G})$ ratio was calculated after 7, 14 and 21 days. Protein profile contents results showed different changes at all experimental periods which sometimes observed some increased or decreased values comparing with normal health control group (I) only but highly significant increase was obtained when compared to diabetic control group (II) only. In view of these facts the improving and protective effect of AEHRS leaves, AEPP and their mixture against male albino rats protein profile was showed.
\end{abstract}

Key words: Hibiscus rosa sinensis, pomegranate (punica granatum) peels, aqueous extract, total protein (TP), albumin (alb), albumin/globulin ratio $(\mathrm{A} / \mathrm{G})$ ratio.

\section{Introduction}

The herb Hibiscus rosa-sinesis Linn (Malvaceae) is a glabrous shrub widely cultivated in the tropics as an ornamental plant and has several forms with varying colours of flowers. In medicine, however the red flowered variety is preferred (Adhirajan et al., 2003) The leaves and flowers are observed to be promoters of hair growth and aid in healing of ulcers (Jadhav et al., 2009). Flowers have been found to be effective in the treatment of arterial hypertension and to have significant antifertility effect (Sethi et al., 1986). Flowers are considered as aphrodisiac, emollient and emmenagogue and the decoction of flowers is used in bronchial catarrh (Pullaiah, 2002) and diarrhoea (Kasture et al., 2000). And also has calcium channel blocking action (Gilani et al., 2005).

Previous studies have demonstrated that flavonoids have remarkable inhibiting effects on protein glycosylation (Asgary et al., 1999 and 2002).

The level of protein in plasma was found to be reduced in diabetic animals when compared to control ones. The lowered level of protein, after the H.rosa sinensis treatment, increased approximated to control. The levels of albumin and albumin/globulin ratio in plasma were decreased in diabetic animals. These lowered levels of plasma albumin and albumin/globulin ratio level were restored significantly in the $H$. rosa sinensis-treated diabetic rats (Mandade and Sreenivas, 2011).

Reduction in plasma total protein and albumin level was observed in diabetic rats and this is consistent with the results obtained by (Bakris, 1997) and (Tuvemo et al., 1997). The decrease in protein and albumin may be due to microprotienuria and albuminuria which are important clinical markers of diabetic nephropathy (Mauer et al., 1981) and/or may be due to increase protein catabolism (Almdal and Vilstrup, 1988). The results of this study demonstrated that the treatment of diabetic rats with the extract of $H$. rosa sinensis caused a noticeable elevation in the plasma total protein and albumin levels as compared with their normal levels (Safiyeh et al., 2007) H. rosa sinensis extract could influence protein metabolism and marker enzymes in STZ-induced diabetic rats. The extract also protect liver and kidney from damage due to diabetes (Zanna et al., 2008).

Goat lens treated with the ethanolic extracts of leaves of hibiscus-rosa sinensis (EEHRS) at concentrations of $1 \mathrm{mg}, 1.5 \mathrm{mg}$ and $2 \mathrm{mg}$ showed significantly $(\mathrm{P}<0.05)$ increased total protein and water soluble protein levels respectively compared to the positive control (Aziz et al., 2015). 
Total 50\% ethanolic and benzene extracts of hibiscus rosa-sinensis treatments showed increase in protein content of the adult female rats markedly depending the dose and duration. The effect is more pronounced at $300 \mathrm{mg} / \mathrm{kg} /$ day level and for 18 days duration. Benzene extract is more potent than the ethanolic extract when given for 12 and 18 days (Prakash, 1979). Enhancement in protein contents of adult female rats treated with hibiscus rosa sinensis extracts may be due to the antiestrogenic nature of the extracts which has already been assayed by (Kholkute et al., 1977). Feeding by hibiscus rosa sinensis flower extract $(240 \mathrm{mg} / \mathrm{kg} \mathrm{bw})$ was more effective on reduction of serum albumin in hypercholesterolemic group may be due to formation of protein adduct, which leads to covalent modification of cellular target protein, cell death and organ damage (Janbaz et al., 1998). The treatment of diabetic and normal rats with aqueous methanolic extract of hibiscus rosa sinensis leaves induced slightly and significant increase in concentration of plasma protein (Zaki et al., 2017).

Pomegranate (Punica granatum L.), a fruit native of the Middle East, has gained widespread popularity as a functional food and nutraceutical source is gaining tremendous attention due to its powerful antioxidant properties (Johanningsmeier and Harris, 2011). The health effects of the whole fruit, as well as its juices and extracts, have been studied in relation to a variety of diseases. Punica granatum (pomegranate) is used as food or as medication in folk medicine for antiviral, anthelmintic, antifungal, antibacterial and antimicrobial activity (Amorim $\boldsymbol{e t}$ al., 2003). Studies have shown that pomegranate products prevent and/or reduced chemically cardiovascular disease and diabetes (Lansky and newman, 2007), induced tumors in skin (Hora et al., 2003), breast (Kim et al., 2002), lung (Khan et al., 2007) and colon (Kohno et al., 2004) in vivo and ex vivo study. Studies showed pomegranate fruit and flower extracts to exhibit freeradicals scavenging properties with simultaneous potent hepatoprotection against chemically induced liver damage in rodents (Celik et al., 2009 and Bishayee et al., 2011)

The effect of pomegranate peel ethanolic extracts on serum proteins (total protein, albumin and globulin) were determined. In the hepatoprotective period, the $\mathrm{CCl}_{4}$-treated group showed a significant reduction in the serum total protein content. Treatment with pomegranate peel ethanolic extracts during $\mathrm{CCl}_{4}$ administration significantly increased the serum total protein content. When compared with $\mathrm{CCl}_{4}$-treated group. In the curative period, the highest increase in serum total protein content was noticed in the rats treated with pomegranate peel ethanolic extracts and no significant difference was found when compared with normal group. From the obtained data in both hepatoprotective and curative periods, treated rats with carbon tetrachloride showed a significant decrease in the serum albumin contents. Treatment rats with pomegranate peel ethanolic extracts significantly increase the serum albumin contents when compared with $\mathrm{CCl}_{4}$-treated group. No significant effects were observed on the serum globulin contents between all groups and normal control in the hepatoprotective period. In the curative period, a relative high increase in serum globulin content was noticed in the rats treated with pomegranate peel ethanolic extracts. (Zafar and Ali, 1998 and Osman et al., 2011).

Determining kidney damage can be carried out by checking biochemical parameter such as the examination of the levels of the total serum protein (Primarizky et al, 2016). The administration of pomegranate extracts as a nephrotoxicity treatment in white rats can maintain the normal levels of total protein.

The induction of pomegranate peel extract PPE during the time course of the experimental period elicited no effect on the levels of total protein and albumin with respect to normal control group. The 15 days pre and 15 days co-administration of (PPE) with oxytetracycline (OTC) caused a well marked increase in serum total protein and albumin levels compared with OTC-treated group (El-sayed et al., 2014).

The aim of this study is to evaluate the possible ameliorative effect of natural products (aqueous extract of hibiscus rosa sinensis leaves, aqueous extract of pomegranate (punica granatum) peels and their mixture on protein profile concentrations (total protein (TP), albumin (alb) and albumin/globulin ratio $(\mathrm{A} / \mathrm{G})$ ratio)) which are very high important for examining kidney and liver damage of male albino rats in order to find new potential sources of natural antioxidants.

\section{Materials and Methods \\ Plant material collection}

The leaves of Hibiscus rosa sinensis were collected from Faculty of Agriculture, Ain Shams University garden, while the fruits of pomegranate (Punica granatum) were purchased from local market. All plant materials were identified and authenticated by Horticulture department, Faculty of Agriculture, Ain Shams University. The samples were washed with distilled water to remove any impurities and dried under shade. Then the dried plant materials were ground into powder with grinder mixture.

\section{Extract preparation}

Boiling distilled water $(500 \mathrm{ml})$ was added to 8 $\mathrm{g}$ pomegranate peels powder and the same conditions with $8 \mathrm{~g}$ powder of Hibiscus rosa sinensis, then left for 10 minutes and filtered. The filtrates were dried at $40-45^{\circ} \mathrm{C}$.

Animals

Male albino rats weighing $120 \pm 10 \mathrm{~g}$ were obtained from experimental farmland animals unit, Ministry of Health, Helwan, Cairo, Egypt. The 
animals were caged and provided with food and water ad-libitum. The rats were kept for one week to adapt to the laboratory conditions before starting of the experiment. The experimental rats (72 animals) adult male albino rats were divided into twelve groups (6 rats/each).

\section{Experimental design}

Three dose levels of each AEHRS leaves and AEPP beside their mixture at four doses, three for normal animals (125/125,225/225 and 350/350) and one for diabetic rats treated with mixture of AEHRS leaves AEPP at dose of $400 / 400 \mathrm{mg} / \mathrm{kg}$ bw. The experiment rats were divided into the following groups.

Group I: normal control rats

Group II: diabetic control by a single intraperitoneal (i.p.) injection of 65 $\mathrm{mg} / \mathrm{kg}$ of streptozotocin (STZ) only.

Group III: normal rats daily received AEHRS leaves of $250 \mathrm{mg} / \mathrm{kg}$ bw .

Group IV: normal rats daily received AEHRS leaves of $500 \mathrm{mg} / \mathrm{kgbw}$.

Group V: normal rats daily received AEHRS leaves of $750 \mathrm{mg} / \mathrm{kg}$ bw

Group VI: normal rats daily received AEPP of $100 \mathrm{mg} / \mathrm{kg}$ bw .

Group VII: normal rats daily received AEPP of $200 \mathrm{mg} / \mathrm{kg}$ bw.

Group VIII: normal rats daily received AEPP of $300 \mathrm{mg} / \mathrm{kg}$ bw.

Group IX: normal rats daily received AEHRS leaves and AEPP mixture of $125 / 125 \mathrm{mg} / \mathrm{kg}$ bw.

Group X: normal rats daily received AEHRS leaves and AEPP mixture of 225/225 mg/kg bw.

Group XI: normal rats daily received AEHRS leaves and AEPP mixture of $350 / 350 \mathrm{mg} / \mathrm{kg}$ bw.

Group XII: diabetic rats daily received AEHRS leaves and AEPP mixture of $400 / 400 \mathrm{mg} / \mathrm{kg}$ bw.

Duration of the experiment was extended for Collection of blood 21days.

The blood was withdrawn from the retroorbital sinus puncture of the eye using mild ether anesthesia. The collected samples were centrifuged for $10 \mathrm{~min}$. (Jadeja et al. 2009) at 7 days, 14 days and 21 days of the experimental period. The protein content in the serum was estimated by the method of Lowry et al., (1951). The albumin content was estimated by the method described by Reinhold, (1980). The serum globulin was calculated by subtraction of serum total protein and serum albumin, as following:

serum globulin $(\mathrm{g} \%)=$ serum total proteinserualbumin.
Albumin/globulin ratio was calculated by dividing each albumin value by its corresponding globulin value.

\section{Chemical and equipments}

All chemicals and equipments used were of analytical grade and purchased from El-Gomhoria Chemicals Co and electoscient chemicals Co.

\section{Statistical analysis}

All the data were expressed as mean \pm SE. Statistical analysis was carried out using student's ttest to analyze the significance between the groups. A value of $\mathrm{P}<0.05$ was considered to be significant Sendecor and Coebram (1969).

\section{Results and Discussion}

Results of serum total protein are presented in Table (1) and figure (1-a,b,c and d). Serum total protein values were $6.9 / \mathrm{g} / \mathrm{dl}, 7.01 \mathrm{~g} / \mathrm{dl}$ and $7.34 \mathrm{~g} / \mathrm{dl}$; $4.01 \mathrm{~g} / \mathrm{dl}, 4.30 \mathrm{~g} / \mathrm{dl}$ and $4.61 \mathrm{~g} / \mathrm{dl} ; 5.91 \mathrm{~g} / \mathrm{dl}, 6.53$ $\mathrm{g} / \mathrm{dl}$ and $6.62 \mathrm{~g} / \mathrm{dl}$ at 7,14 and 21 days of the experimental period for normal control (I), diabetic control (II) and last group (diabetic rats treated with 400/400 - XII) respectively. Also, the results showed that different doses of natural products (AEHRS leaves and AEPP) significantly increased serum total protein in all groups after 7 days when compared to normal control, diabetic control and the curative diabetic group (XII). The results also indicated that increasing doses of AEHRS leaves, AEPP and their combination led to increase serum total protein when compared to the I, II and XII groups after 14 days. On the other hand, after 21 days in all groups the serum total protein decreased relative to normal control (7.34 \pm 0.39$)$ only. This elevation of serum total protein after 7 and 14 days may be due to that different doses of natural product (AEHRS leaves and AEPP) effect on either the regulation of serum and liver proteins levels by stimulating the protein biosynthesis to produce specific enzymes to antagonize the harmful effect of free radicals and also by stimulating certain endocrine gland activity for excretion the hormones which regulated protein metabolism. The results obtained cleared that both AEHRS leaves and AEPP individually or in combination increased serum total protein which are in agreement with Biswas et al., (2014) they reported that feeding of hibiscus rosa sinensis flower extract for four weeks to hypercholesterolaemic rats significantly $(\mathrm{P}<0.001)$ increased in total protein (TP) levels compared to the hypercholesterolaemic control group. Abd El-Monem,( 2014) found that pomegranate molasses (PM) supplementation together with Diazinon (DZN) improved the values of serum total protein (TP). This may be attributed to the powerful antioxidants such as polyphenol, total phenols and total flavonoids. 
Table (1) and figure (1-a,b,c and d): Effect of different concentrations of natural products (aqueous extract of hibiscus rosa-sinensis leaves -(AEHRS), aqueous extract of pomegranate (punica granatum) peels (AEPP)) and their mixture on serum total protein (g/dl) in male albino rats

\begin{tabular}{|c|c|c|c|c|c|c|c|c|c|c|c|c|}
\hline \multirow{2}{*}{ Treatments } & \multirow[b]{2}{*}{$\begin{array}{l}\text { Normal } \\
\text { control }\end{array}$} & \multirow[b]{2}{*}{$\begin{array}{l}\text { Diabetic } \\
\text { control }\end{array}$} & \multicolumn{3}{|c|}{ AEHRS leaves (mg/kg bw) } & \multicolumn{3}{|c|}{ AEPP (mg/kg bw) } & \multicolumn{4}{|c|}{$\begin{array}{c}\text { AEHRS leaves and AEPP mixture (mg/kg } \\
\text { bw) }\end{array}$} \\
\hline & & & 250 & 500 & 750 & 100 & 200 & 300 & $125 / 125$ & $225 / 225$ & $\mathbf{3 5 0} / \mathbf{3 5 0}$ & $\begin{array}{c}\text { Diabetic } \\
\text { rats }+ \\
\mathbf{4 0 0} / \mathbf{4 0 0}\end{array}$ \\
\hline 7 & $6.91 \pm 0.85$ & $4.01 \pm 0.77$ & $8.13 \pm 0.31 *$ & $7.51 \pm 0.37$ & $9.51 \pm 0.79 *$ & $7.51 \pm 0.55$ & $7.99 \pm 0.99$ & $8.50 \pm 0.58$ & $9.11 \pm 0.88^{*}$ & $8.55 \pm 0.44$ & $9.69 \pm 0.39 *$ & $5.91 \pm 0.42$ \\
\hline 14 & $7.01 \pm 0.55$ & $4.30 \pm 0.88$ & $7.11 \pm 0.91$ & $8.10 \pm 0.95$ & $8.59 \pm 0.96$ & $7.21 \pm 0.76$ & $7.91 \pm 0.78$ & $8.22 \pm 0.73$ & $8.21 \pm 0.66$ & $8.51 \pm 0.33$ & $9.75 \pm 0.93 *$ & $6.53 \pm 0.55$ \\
\hline 21 & $7.34 \pm 0.39$ & $4.61 \pm 0.91$ & $6.99 \pm 0.37$ & $6.91 \pm 0.93$ & $6.87 \pm 0.88$ & $6.73 \pm 0.70$ & $6.80 \pm 0.44$ & $7.13 \pm 0.40$ & $7.01 \pm 0.55$ & $7.21 \pm 0.11$ & $7.20 \pm 0.39$ & $6.62 \pm 0.33$ \\
\hline
\end{tabular}

Values are expressed as mean \pm SE. $n=6$

significant difference $(\mathrm{P}<0.05)$ compared with normal control and diabetic control groups 


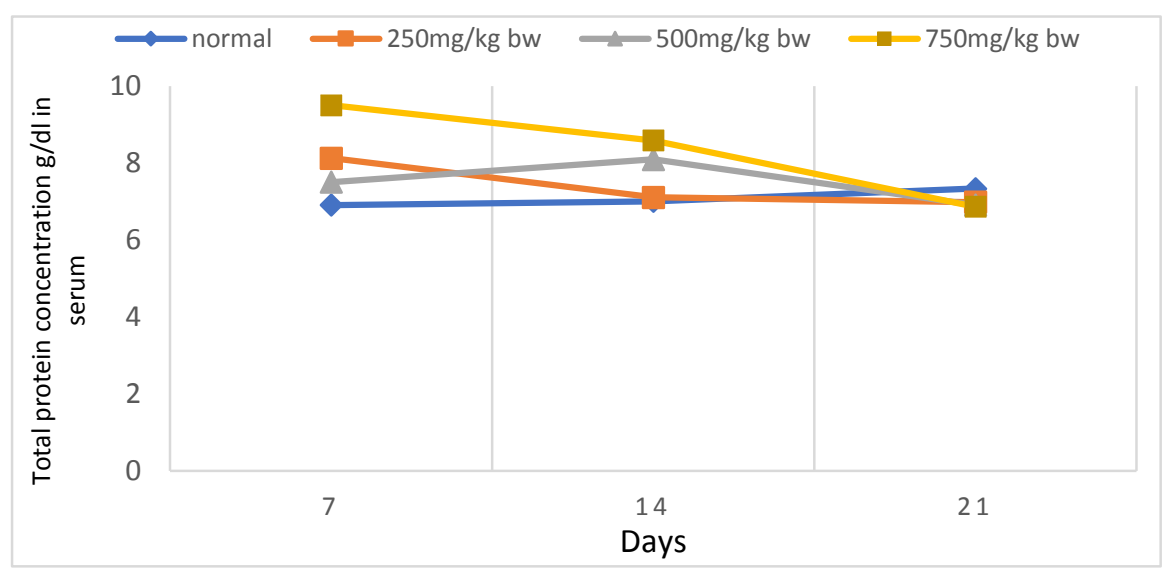

(a)Effect of different concentrations of AEHRS leaves on serum total protein $\mathrm{g} / \mathrm{dl}$

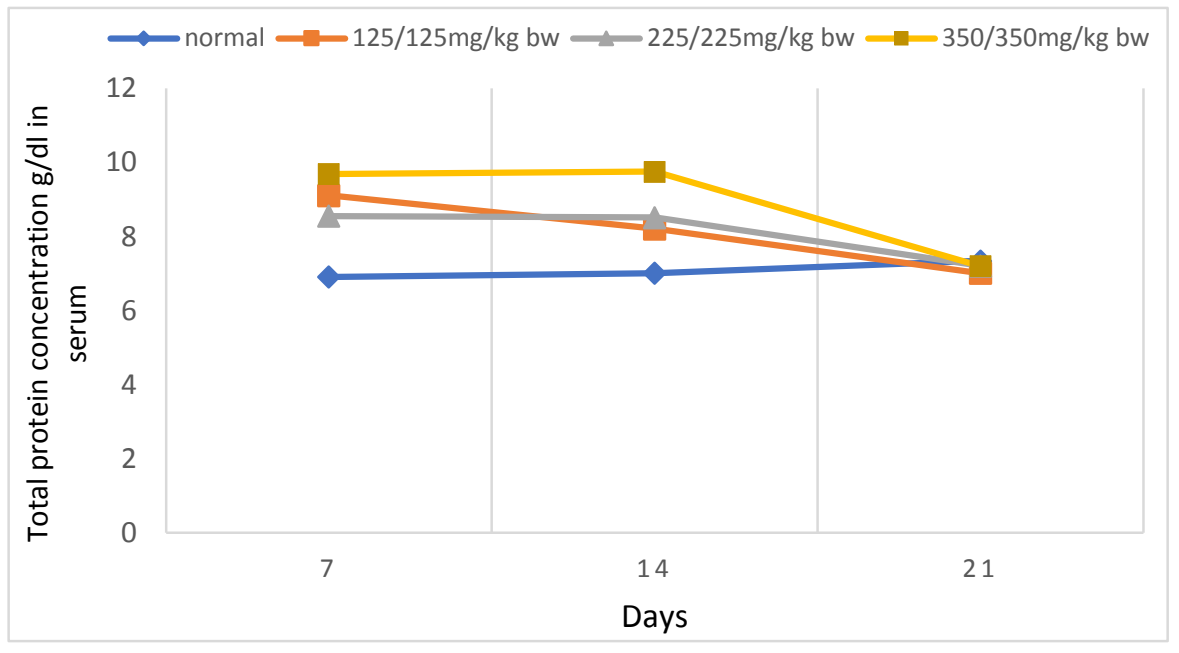

(c)Effect of different concentrations of AEHRS leaves and AEPP mixture on serum total protein $\mathrm{g} / \mathrm{dl}$

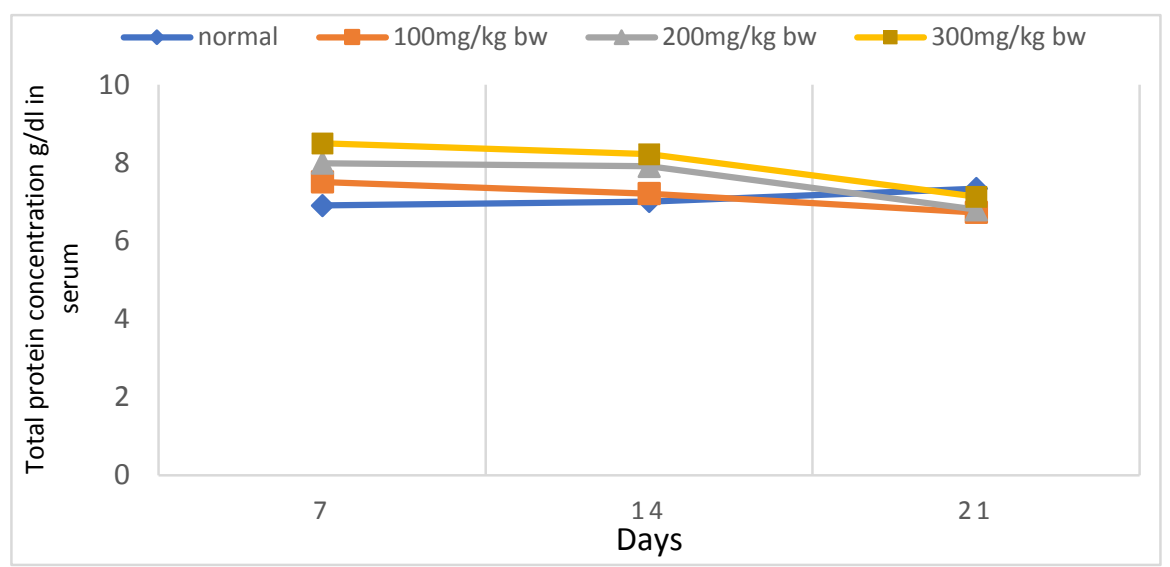

(b)Effect of different concentrations of AEPP on serum total protein $\mathrm{g} / \mathrm{dl}$

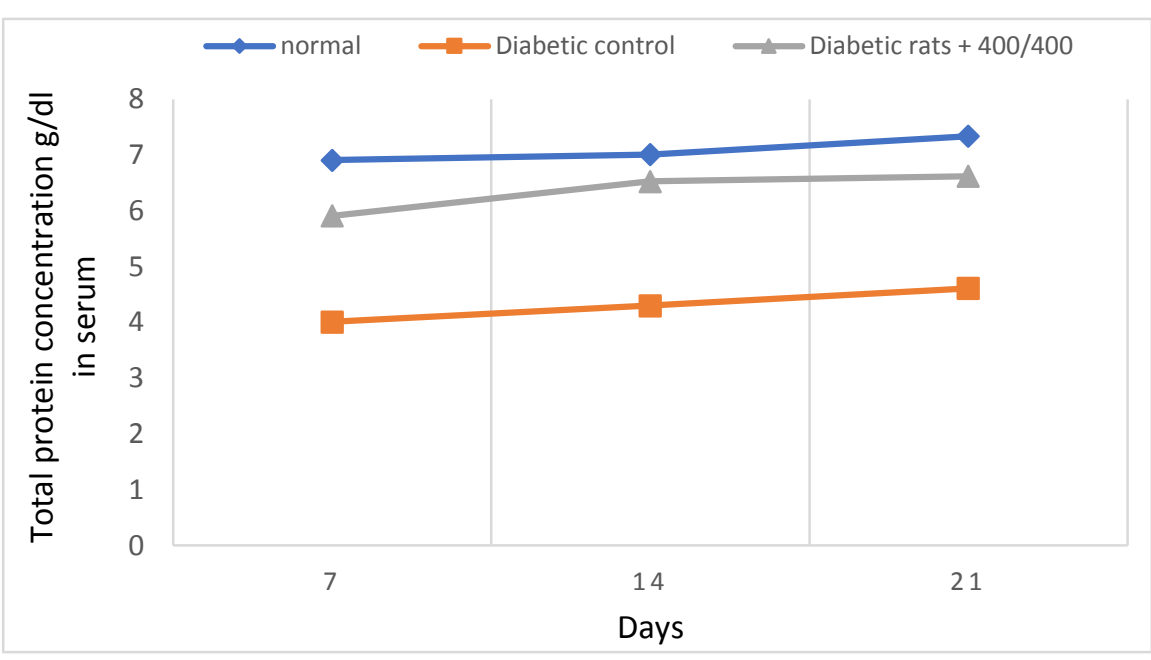

(d)Effect of AEHRS leaves and AEPP mixture on serum total protein $\mathrm{g} / \mathrm{dl}$ in Diabetic rats 
Data are represented in Table (2) and figure (2-a,b,c and d) indicated that different doses of natural products either in single dose or in mixtures led to elevation of serum albumin in rats after 7 days of experiment comparing to I, II and XII groups except low dose of AEHRS leaves which showed slightly decrease of this value which $(3.89 \mathrm{~g} / \mathrm{dl})$ when compared with normal control (I) (4.08 g/dl) only. These findings are coincided with Mandade and Sreenivas, (2011) who noticed that administration of hibiscus rosa sinensis $(500 \mathrm{mg} / \mathrm{kg})$ aqueous extract to diabetic rats for four weeks significantly elevated plasma albumin. Also, the present results agree with Abd El-Monem,( 2014) results who found that serum albumin (Alb) was increased in male rats which given $0.5 \mathrm{ml}$ pomegranate molasses plus 0.5 $\mathrm{ml}$ distilled water/day for 10 days when compared to normal control. On the other hand, respect to serum albumin after 14 days data revealed significant increase in this value in all groups when compared to I, II and XII groups except the groups of rats which received medium dose of AEHRS leaves and AEPP which showed lowering in serum albumin when compared to normal control (I).

Regarding to this parameter, after 21 days the present results showed reduction in serum albumin of rats orally daily administrated with AEHRS leaves when compared to normal control (I). Meanwhile a remarkable increase was shown in serum albumin in rats received AEPP in low or high dose .The values were $5.31 \mathrm{~g} / \mathrm{dl}$ and $5.61 \mathrm{~g} / \mathrm{dl}$ comparing to $4.69 \mathrm{~g} / \mathrm{dl}, 1.76 \mathrm{~g} / \mathrm{dl}$ and $3.78 \mathrm{~g} / \mathrm{dl}$ in normal control, diabetic control and last group (XII) respectively. In contrary medium dose of AEPP showed lowering serum albumin when compared to normal control only. In addition, the groups of rats orally administrated daily mixture of AEHRS leaves and AEPP showed some increasing in serum albumin comparing to I, II and XII groups except the rats orally administrated daily mixture of AEHRS leaves and AEPP with dose $350 / 350 \mathrm{mg} / \mathrm{kg}$ bw (group XI) which showed lowering in serum albumin when compared to normal control $(4.69 \pm 0.63 \mathrm{~g} / \mathrm{dl})$. It could be saying that AEPP was more effective in increasing serum albumin compared with AEHRS leaves which cleared after 21 days. Also, the mixture dose generally increased serum albumin and this raising cleared too after 21 days especially in groups IX and $\mathrm{X}$ when compared with normal control, diabetic control and the last group ( XII). These results are in accordance with Salim et al., (2014) who mentioned that groups treated with pomegranate seeds alone or pomegranate seeds supplemented to dimethoate treated group caused very significant improved $(\mathrm{P}<0.05)$ in serum albumin level. 
Table (2) and figure (2-a, b, c and d): Effect of different concentrations of natural products (aqueous extract of hibiscus rosa-sinensis leaves (AEHRS ), aqueous extract of pomegranate (punica granatum) peels (AEPP)) and their mixture on serum albumin (g/dl) in male albino rats

\begin{tabular}{|c|c|c|c|c|c|c|c|c|c|c|c|c|}
\hline \multirow[b]{2}{*}{ Days } & \multirow[b]{2}{*}{$\begin{array}{l}\text { Normal } \\
\text { control }\end{array}$} & \multirow[b]{2}{*}{$\begin{array}{l}\text { Diabetic } \\
\text { control }\end{array}$} & \multicolumn{3}{|c|}{ AEHRS leaves (mg/kg bw) } & \multicolumn{3}{|c|}{$\operatorname{AEPP}(\mathbf{m g} / k g$ bw) } & \multicolumn{4}{|c|}{$\begin{array}{c}\text { AEHRS leaves and AEPP mixture (mg/kg } \\
\text { bw) }\end{array}$} \\
\hline & & & 250 & 500 & 750 & 100 & 200 & 300 & $125 / 125$ & $225 / 225$ & $350 / 350$ & $\begin{array}{c}\text { Diabetic } \\
\text { rats }+ \\
\mathbf{4 0 0} / \mathbf{4 0 0}\end{array}$ \\
\hline 7 & $4.08 \pm 0.43$ & $1.52 \pm 0.23$ & $3.89 \pm 0.91$ & $4.31 \pm 0.37$ & $4.91 \pm 0.93$ & $4.58 \pm 0.31$ & $5.01 \pm 0.77$ & $5.31 \pm 0.44$ & $4.78 \pm 0.78$ & $4.89 \pm 0.88$ & $5.31 \pm 0.55$ & $3.40 \pm 0.25$ \\
\hline 14 & $4.53 \pm 0.50$ & $1.65 \pm 0.44$ & $4.61 \pm 0.57$ & $3.84 \pm 0.99 *$ & $4.93 \pm 0.77$ & $5.02 \pm 0.58^{*}$ & $4.01 \pm 0.56^{*}$ & $4.98 \pm 0.88$ & $5.81 \pm 0.99 *$ & $4.97 \pm 0.93$ & $5.06 \pm 0.78 *$ & $3.51 \pm 0.37$ \\
\hline 21 & $4.69 \pm 0.63$ & $1.76 \pm 0.78$ & $4.03 \pm 0.89$ & $3.99 \pm 0.95$ & $4.53 \pm 0.55$ & $5.31 \pm 0.49 *$ & $4.00 \pm 0.59$ & $5.61 \pm 0.47 *$ & $4.93 \pm 0.55$ & $4.88 \pm 0.66$ & $4.13 \pm 0.73$ & $3.78 \pm 0.93$ \\
\hline
\end{tabular}

Values are expressed as mean \pm SE. $n=6$

significant difference $(\mathrm{P}<0.05)$ compared with normal control and diabetic control groups 


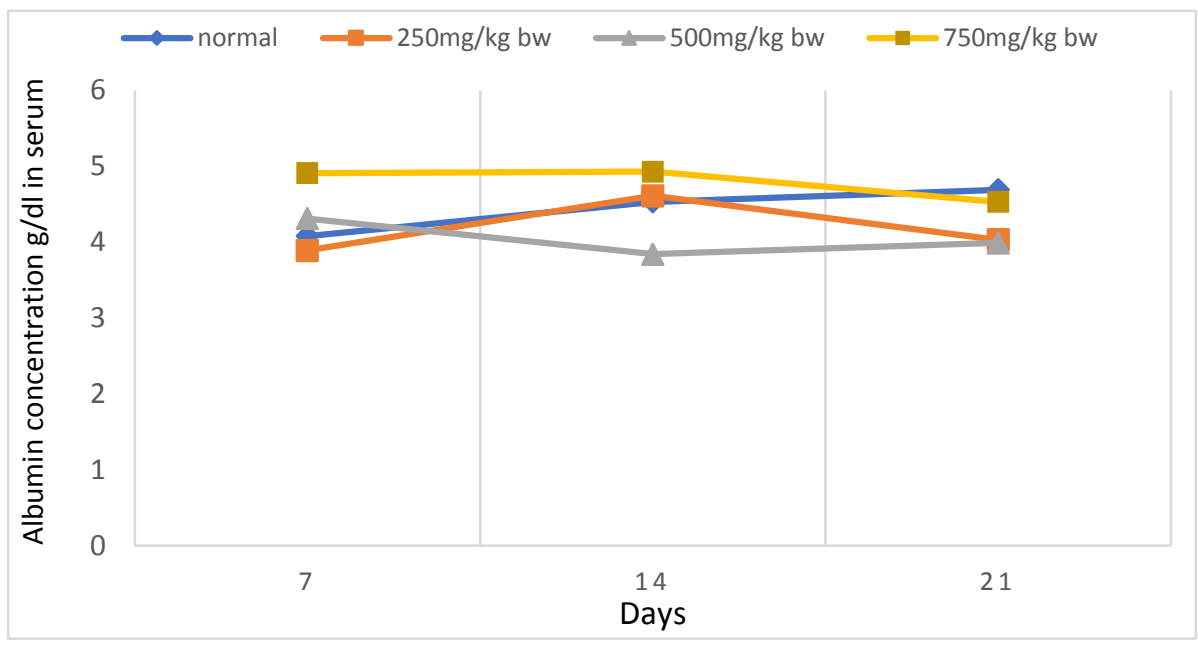

(a)Effect of different concentrations of AEHRS leaves on serum Albumin g/dl

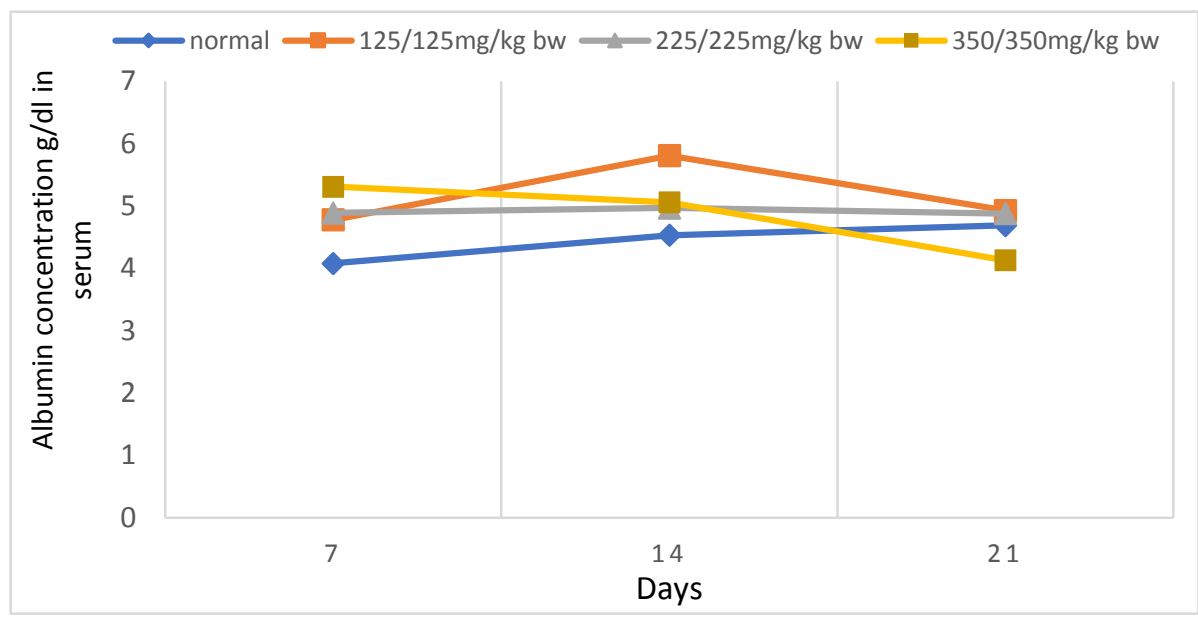

(c)Effect of different concentrations of AEHRS leaves and AEPP mixture on serum Albumin $\mathrm{g} / \mathrm{dl}$

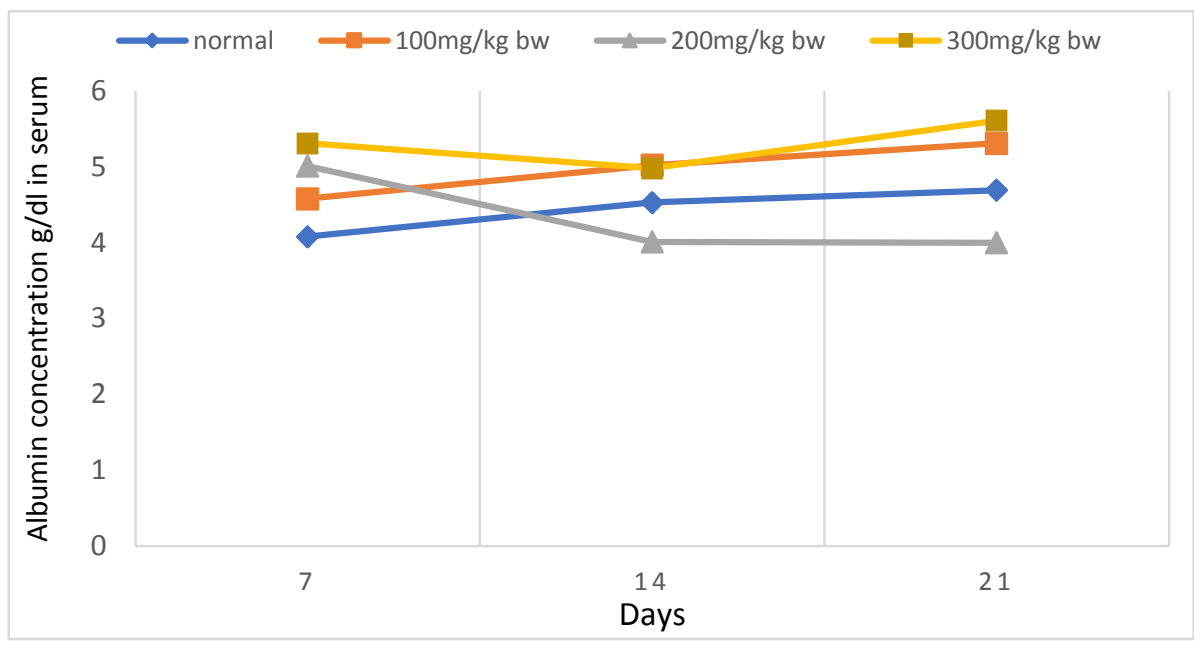

(b)Effect of different concentrations of AEPP on serum Albumin g/dl

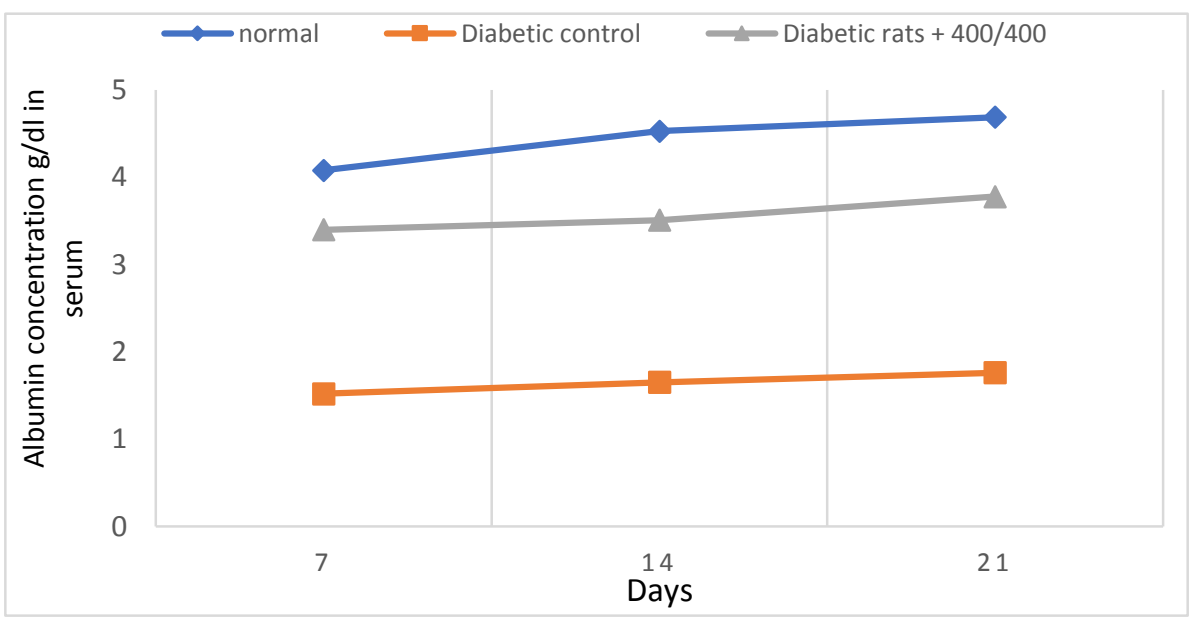

(d)Effect of AEHRS leaves and AEPP mixture on serum Albumin $\mathrm{g} / \mathrm{dl}$ in Diabetic rats 
Results obtained in Table (3) and figure (3) represented the calculated ratio of serum albumin to globulin ( $\mathrm{A} / \mathrm{G}$ ratio) in male albino rats under investigation. The ratio showed an elevation in this value through 7 and 14 days $(1.44 \pm 0.17$ and $1.82 \pm 0.09$ respectively) then return to reduction after 21 days (1.76 \pm 0.08$)$ in normal control rats (I). Also, the same trend was observed in diabetic control group (II).

On the other hand, opposite trend was cleared in last group (XII) (diabetic rats + 400/400). Meanwhile, after 7 days observed in all groups lowering of serum albumin / globulin ratio except low, medium and high doses of AEPP which showed an elevation in $\mathrm{A} / \mathrm{G}$ ratio which reached to $(1.56,1.68$ and 1.66 respectively) when compared to normal control (I) (1.44) and the last group (XII) (1.35). However, data represented in Table (3) indicated that all different doses of natural products
(AEHRS leaves and AEPP) decreased serum albumin/globulin ratio in rats after 14 days except low doses of AEHRS leaves, AEPP and their mixture which showed increase of $\mathrm{A} / \mathrm{G}$ ratio $(1.84,2.29$ and 2.42 respectively) when compared to normal control (I) (1.82). These results are in agreement with Mandade and Sreenivas, (2011). A/G ratio at 7, 14 and 21 days revealed that this parameter was increased in all groups under study with a single dose or a mixture doses of AEHRS leaves and AEPP when compared to diabetic control (II). Meanwhile, the ratio indicated that different changes after 14 days which sometimes showed some increase or decrease comparing with the same value after 7 and 21 days but in all time this value was given the highest ratio with lowest dose of AEPP after 21 days. However, our data are in good agreement with stated by Abd El-Monem,(2014). 
Table (3) and figure (3): Effect of different concentrations of natural products (aqueous extract of hibiscus rosa-sinensis leaves (AEHRS), aqueous extract of pomegranate (punica granatum) peels (AEPP)) and their mixture on serum albumin/globulin ratio in male albino rats

\begin{tabular}{|c|c|c|c|c|c|c|c|c|c|c|c|c|}
\hline \multirow[b]{2}{*}{ Days } & \multirow[b]{2}{*}{$\begin{array}{l}\text { Normal } \\
\text { control }\end{array}$} & \multirow[b]{2}{*}{$\begin{array}{l}\text { Diabetic } \\
\text { control }\end{array}$} & \multicolumn{3}{|c|}{ AEHRS leaves (mg/kg bw) } & \multicolumn{3}{|c|}{$\operatorname{AEPP}(\mathbf{m g} / \mathbf{k g ~ b w})$} & \multicolumn{4}{|c|}{$\begin{array}{l}\text { AEHRS leaves and AEPP mixture (mg/kg } \\
\text { bw) }\end{array}$} \\
\hline & & & 250 & 500 & 750 & 100 & 200 & 300 & $125 / 125$ & $225 / 225$ & $350 / 350$ & $\begin{array}{c}\text { Diabetic } \\
\text { rats }+ \\
\mathbf{4 0 0} / \mathbf{4 0 0}\end{array}$ \\
\hline 7 & $1.44 \pm 0.17$ & $0.61 \pm 0.04$ & $0.91 \pm 0.09$ & $1.34 \pm 0.08$ & $1.06 \pm 0.08$ & $1.56 \pm 0.09$ & $1.68 \pm 0.04$ & $1.66 \pm 0.03$ & $1.10 \pm 0.14$ & $1.33 \pm 0.09$ & $1.21 \pm 0.12$ & $1.35 \pm 0.09$ \\
\hline 14 & $1.82 \pm 0.09$ & $0.62 \pm 0.05$ & $1.84 \pm 0.03$ & $0.90 \pm 0.05$ & $1.34 \pm 0.09$ & $2.29 \pm 0.29$ & $1.02 \pm 0.05$ & $1.53 \pm 0.12$ & $2.42 \pm 0.31$ & $1.40 \pm 0.03$ & $1.07 \pm 0.18$ & $1.16 \pm 0.08$ \\
\hline 21 & $1.76 \pm 0.08$ & $0.61 \pm 0.07$ & $1.36 \pm 0.05$ & $1.36 \pm 0.08$ & $1.93 \pm 0.15$ & $3.73 \pm 0.28$ & $1.42 \pm 0.02$ & $3.69 \pm 0.47$ & $2.37 \pm 0.22$ & $2.09 \pm 0.07$ & $1.34 \pm 0.09$ & $1.33 \pm 0.07$ \\
\hline
\end{tabular}

Values are expressed as mean \pm SE. $\mathrm{n}=6 \quad$ significant difference $(\mathrm{P}<0.05)$ compared with normal control and diabetic control groups

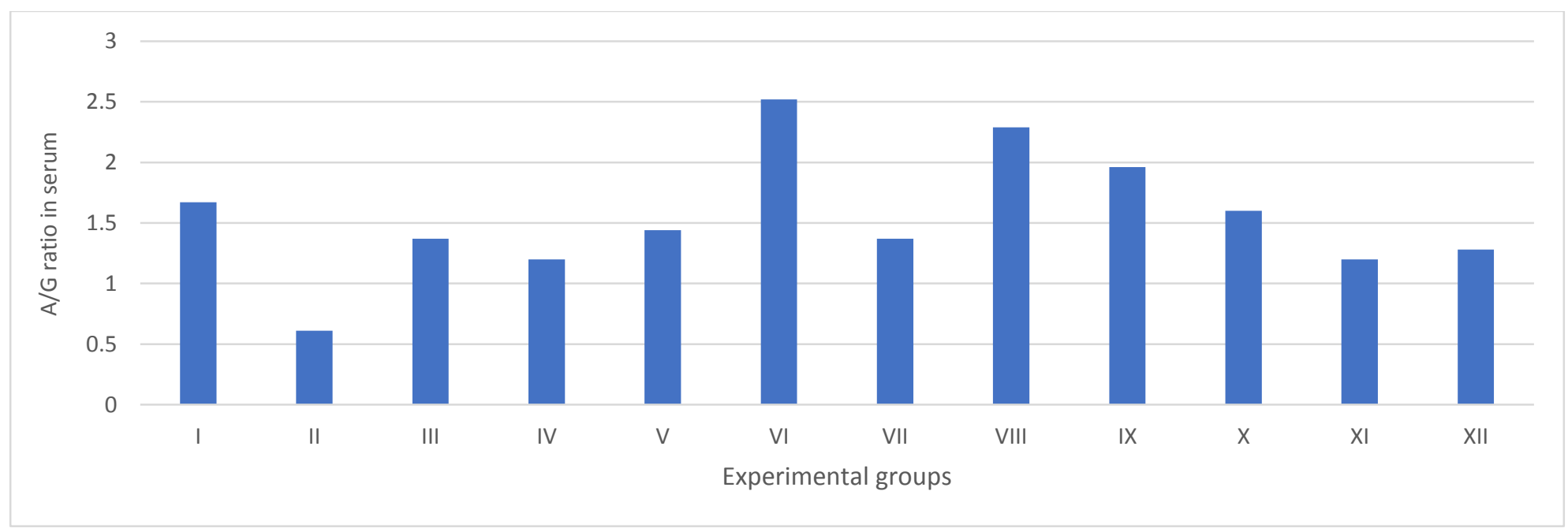




\section{Conclusion}

Results therefore, show that, the oral administration of natural products (aqueous extract of hibiscus rosa sinensis leaves, aqueous extract of pomegranate (punica granatum) peels and their mixture) increased total protein, albumin and albumin/globulin ratio when compared to diabetic control group (II) in albino rats. The use of the plants may have a pleasant effect on the kidney.

\section{References}

Abd-El-monem, H.A. (2014). Assessment the effect of pomegranate molasses against diazinon toxicity in male rats. IOSR Journal of Envir. Sci.Toxicol. Food Technol. 2(8): 135-141.

Adhirajan, N.; T.R. Kumar; N. Shanmugasundaram and M. Babu, (2003). In vivo and in vitro evaluation of hair growth potential of hibiscus rosa-sinensis Li. J. Ethnopharmacol 88: 235-239.

Almdal, J.P. and H. Vilstrup (1988). Strict insulin therapy nonnalizes organ nitrogen contents and capacity of urea nitrogen synthesis in experimental diabetes in rats, Diabetlogia, 31: 114-118.

Amorim, L.F.; M.T. Catanho; D.A. Terra; K.C. Brandao; C.M. Holanda; L.H. Jales Junior; L.M. Brito; M.L. Gomes; V.G. De Melo and M. Bernardo Filho (2003). " Cavalcanti Jales RL, cell Mol Biol. (Noisy-le-grand) Jun: 49(4): 501-507.

Asgary, S., G.A. Naderi, S.N. Zadegan and R. Vakili (2002). The inhibitory effects of pure flavonoids on in vitro protein glycosylation. J. Herbal Pharmacother. 2: 47-55.

Asgary, S., G.A. Naderi, N. Sarrafzadegan and M. Ghasemi (1999). Antioxidant effect of flavonoids on hemoglobin glycosylation. Phar. Acta Helv. 73: 223-226.

Aziz, S.; M. Konwar and S. Das (2015). In-vitro anticataract activity of hibiscus rosa-sinensis Linn on Goat lens. Int .J .of pharmacy and pharmaceutical sci. 7 (5):334-336.

Bakris, G.L. (1997). Diabetic nephropathy. What you need to know to preserve kidney function Postgrad Med., 93: 89-100.

Bishayee, A., B. Deepa; J.R. Thoppil; S.A. Darvesh; N. Eviatar and P.E. Lansky (2011). "Pomegranate-mediated chemoprevention of experimental hepatocarcinogenesis involves Nrf2-regulated antioxidant mechanisms, "Carcinogenesis, 32 (6): 888-896.

Biswas, A.; U.J.A.D. Souza; S. Bhat and D. Damodar (2014). The hepato protective effect of hibiscus rosa sinensis flower extract on dietinduced hypercholesterolaemia in male albino wistar rats. Int. J. Med. Pharm. Sci. 04 (06): 1-10.

Celik, I.; A. Temur and I. Isik (2009). "Hepatoprotective role and antioxidant capacity of pomegranate (Punica granatum) flowers infusion against trichloroacetic acid-exposed in rats", Food Chem. Toxicol., 47(1) :145-149.

Elsayed, A.S.; A.M. Badawi and M.T. Asmaa (2014). The protective effect of olive leaf and pomegranate peel extracts on oxidative stress and liver in jury induced by oxytetracycline in albino rats. J. Drug Res. Egypt, 35(1): 33-41.

Gilani, A.H.; S. Bashir; K.H. Janbaz and AJ. Shah (2005). Presence of cholinergic and calcium channel blocking activities explains the traditional use of hibiscus rosa sinensis in constipation and diarrhoea. J. Ethnopharmacol., 102: 289-294.

Hora, J.J.; E.R. Maydew; E.P. Lansky and C. Dwived (2003). "Chemopreventive effects of pomegranate seed oil on skin tumor development in CDI mice," J. Med. Food, 6(3): 157-161.

Jadeja, R.N.; M.G. Thovnaojam; V. Patel; R.V. DevKar and A.V. Ramachandran (2009). Antihyperlipidemic potential of a polyherbal preparation on triton WR 1339 (Tyloxapol) induced hyperlipidemia: A comparison with lovastatin. Int. J. Green Pharm., 3 (3): 119-124.

Jadhav, V.M.; R.M. Thorat; V.J. Kadam and N.S. Sathe (2009). Traditional medicinal uses of hibiscus rosa-sinensis. J. Pharmacy Res., 2: 12201222.

Janbaz, K.H.; S.A. Saeed and A.H. Gilani (1998). An assessment of the potential of protopine to inhibit microsomal drug metabolizing enzymes and prevent chemical induced hepatotoxicity in rodents. Pharmacol. Res, 38: 215-18

Johanningsmeier, S.D. and G.K. Harris (2011). "Pomegranate as a functional food and nutraceutical source," Ann. Rev. Food Technol. 2: 181-201.

Kasture, V.S.; C.T. Chopde and V.K. Deshmukh (2000). Anticonvulsive activity of Albizzia lebbeck, Hibiscus rosa sinensis and Butea monosperma in experimental animals. J. Ethnophannacol., 71:65-75.

Khan, N.; F. Afaq; M.H. Kweon; K. Kim and H. Mukhtar (2007). "Oral consumption of pomegranate fruit extract inhibits growth and progression of primary lung tumors in mice, "Cancer Res, 67:3475-3482.

Kholkute, S.D.; V. Mudgal and K.N. Udupa (1977). Studies on the antifertility potentiality of hibiscus rosa sinensis Linn: Planta Medica 3135.

Kim, N.D.; R. Mehta; W. Yu; I. Neeman; T. Livney; A.A. Poirier; P. Nicholls; A. Kirby; W. Jiang; R. Mansel; C. Ramachandran; T. Rabi; B. Kaplan and E. Lansky (2002). "Chemopreventive and adjuvant therapeutic potential of pomegranate (Punica granatum) for human breast cancer," Breast Cancer Res Treat, 71: 203-217. 
Kohno, H.; R. Suzuki; Y. Yasui; M. Hosokawa and K. Miyashita (2004). "Pomegranate seed oil rich in conjugated linolenic acid suppresses chemically induced colon carcinogenesis in rats, "Cancer Sci.. 95 :481-486.

Lansky, E.P. and R.A. Newman (2007). "Punica granatum (pomegranate) and its potential for prevention and treatment of inflammation and cancer, "J. Ethnopharmacol, 109: 177-206.

Lowry, O.H.; N.J. Rosebrough; A.L. Farr and R.J. Randall (1951). Protein measurement with the folin phenol reagent. J. Biol. Chem., 193: 265-275.

Mandade, R. and S.A. Sreenivas (2011). AntiDiabetic effect of aqueous ethanolic extract of hibiscus rosa sinensis L. on streptozotocin induced diabetic rats and the possible morphologic changes in the liver and kidney. Int. J. pharmacol. 7(3): 363-369.

Mauer, S.M.; M.W. Steffes and D.M. Brown (1981). The kidney in diabetes. Am. Med., 70 :603-612.

Osman, M.; M. Ahmed; S. Mahfouz and S. Elaby (2011). Biochemical studies on the hepta protective effects of pomegranate and Guava ethanol extracts. New York .Sci J, 4(3): 27-41.

Prakash, A.O. (1979). Protein concentration in rat uterus under the influence of Hibiscus rosasinensis Linn. extracts. Proc. Indian Natn. Sci., Acad., B45 ( 4 ) :327-331.

Primarizky, H.; W.M. Yuniarti and B.S. Lukiswanto (2016). Benefits of (Punica granatum Linn) extracts to weight changes, fruit rats total protein, and uric acid in white(Rattus norvegicus) as an animal model of acute renal failure. Veterinary world all) 1269-1274.

Pullaiah, T. (2002). Medicinal Plants in Andhra Pradesh. Regency Publication, New Delhi, India, pp: 143-144, 288.

Reinhold, J. (1980). Determination of Serum Total Protein Albumin and Globulin Fractions by the Biuret Method Int Practical Clinical Biochemistry, Varley, H.A.H. Gowen Lock and
M. Bell(Eds.). 5th Edn., William Heinemann Medical Book Ltd., London, pp: 545-547.

Safiyeh, S.; F. Fathallah; N. Vahid; S.S. Habib and N. Nabat (2007). Effect of Equisetum arvense L. (Equisetaceae) in microalbuminuria and creatinine excretion in streptozotocin-induced diabetes in male rats. Int. J. Pharmacol., 3: 155159.

Salim, A.; A.A.K. Abou-Arab; S.R. Mohamed and T.A. Eldesouky (2014). Influence of pomegranate (punica grantaum L.) on Dimethoate induced Hepatotxicity in Rats. Inter. J. Biol.Biomol.Agric.Food Biotechnol. Eng.8 ( 8): 925-930.

Sendecor,G.W.and W.C.Coebram(1969).In:Statistical methods". ${ }^{\text {th }}$ ed.Lowa state univ.,press Anes,Lowa,U.S.A.p.70.

Sethi, N.; D. Nath and R.K. Singh (1986). Teratological study of an indigenous antifertility medicine, hibiscus rosa-sinensis in rats. Arogya J. Health Sci., 12: 86-88.

Tuvemo, T.; U. Evald; M. Kobbah and L.A. Proos (1997). Serum magnesium and protein concentration during the 1st five years of insulin dependent diabetes in children. Acta Paed. Suppl. 418: 7-10.

Zafar, R. and S.M. Ali (1998). Anti-hepatotoxic effects of root and root callus extracts of Cichorium intybus L. J. Ethnopharmacol. 63 (3): 277.

Zaki, L.H.; S.M. Mohamed; S.A.E. Bashandy; F.A. Morsy; K.M. Tawfic and A.A. Shahat (2017). Hypoglycemic and antioxidant effects of hibiscus rosa sinensis (HRS) L. leaves extract on liver and kidney damage in streptozotocin induced diabetic rats, Afr J. Pharm. Pharmacol, 11(13):161-169.

Zanna, H; S. Adeniji; B.B. Shehu; S. Modu and G.M. Ishaq (2008). Effects of aqueous suspension of the root of hyphaene thebaica (L.) mart on some indicators of liver and kidney function in rats. J. Pharmacol. Toxicol., 3: 330334. 
الهراسات كيميائية على مستويات بروتينات الام فى الجرذان البيضاء تحت تأثير المستخلصات المائية لأولق نبات

\author{
محمود شكرى صادق السيد \\ قسم الكيمياء الحيوية -كلية الزراعة-جامعة عين شمس صكادي القاهرة-مصر
}

أوراق الهيبسكس روزا سيننسس وقشور الرمان لها تطبيقات طبية عديدة.حيث تم دراسة تأثيرهذة الهنتجات الطبيعية (مستخلص أوراق

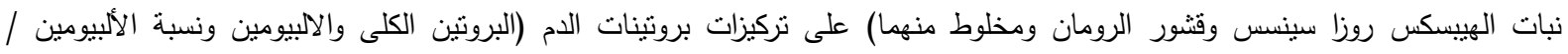

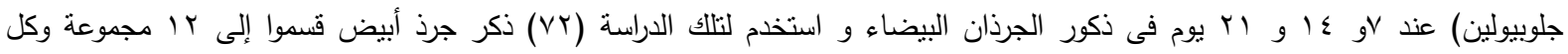

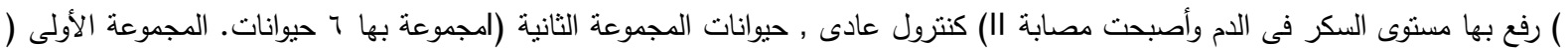

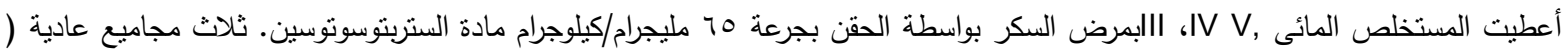

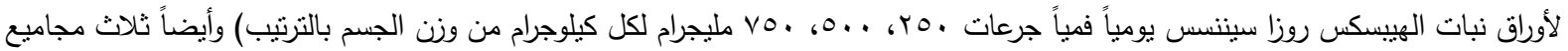

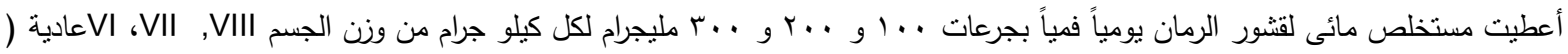

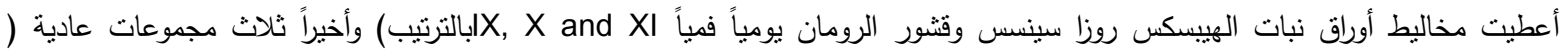

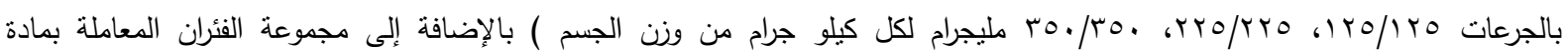

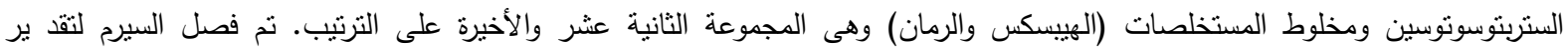

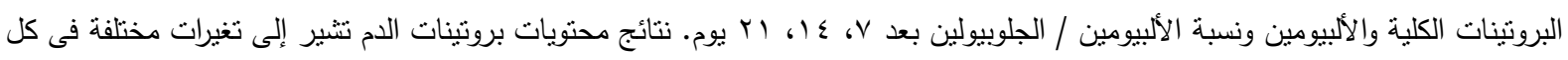

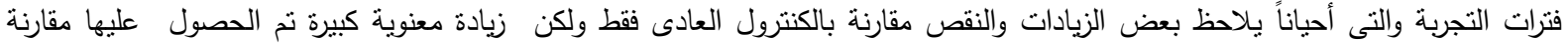

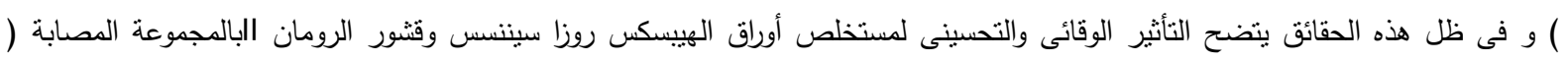
ومخليطها ضد تلف الكبد والكلى فى ذكور الفئران البيضاء. 